\title{
A REAPPRAAISAL OF THE GEOLOGY, GEOCHEMISTRY, STRUCTURES AND TECTONICS OF THE MOZAMBIQUE BELT IN KENYA, EAST OF THE RIFT SYSTEM
}

\author{
C.M. Nyamai ${ }^{1}$, E.M. Mathu ${ }^{1}$, N. Opiyo-Akech ${ }^{1}$ and E. Wallbrecher ${ }^{2}$ \\ 1. Department of Geology, University of Nairobi, P.O. Box 30197, Nairobi, Kenya. \\ 2. Institut fur Geologie and Palaeontologie, Karl-Franzes Universitat, \\ Graz, Heinrichstrasse, 26, A-8010, Austria
}

\begin{abstract}
The largest segment of the Neoproterozoic Mozambique belt in Kenya occurs east of the north-south oriented Rift system. Geological works carried out in the country during the last few decades have progressively revealed the complexity of the geology, structures and tectonics of the Mozambique belt in the region. Important high grade tectono-thermal events in the belt took place between about 845 and $715 \mathrm{Ma}$. The tectonothermal events attained P/T conditions of $5.5-7.1$ kbars and $500-750^{\circ}$ C. The subsequent cooling and uplift of the basement has been traced by $\mathrm{K}$-Ar dates on biotites, which range between 528 and $438 \mathrm{Ma}$. New lithological units established in the last two decades include widespread granitoid, anorthositic, gabbroic to ultramafic intrusions and limited andesitic volcanics in the central region of this eastern segment of the Mozambique belt (EMBS). Previously the geology of this central region had been considered to consist predominantly of pelitic and semi-pelitic schists and gneisses, migmatites and amphibolites. Further north in the Chanler's Falls and Archer's Post areas, this segment is dominated by paragneisses and schists, marbles and calc-silicate rocks, granulites, as well as metamorphosed mafic and ultramafic rocks. A similar lithological metamorphic assemblage as the one in the north is repeatedly noted in the southern part of the belt. Here in the Taita Hills region, close to the Tanzanian border, paragneisses, marbles, amphibolites and metamorphosed ultramafic rocks, with ophiolitic signatures are widespread. West of the Taita Hills in Kajiado district, quartzites are an additional rock unit while meta-ultramafic rocks are notably absent. Complex folding, exhibiting at least three fold generations, and which occasionally have formed elliptical dome and basin structures, are widespread. These are particularly common in the central region of the EMBS. The entire segment however, has several Neoproterozoic faults, thrust and shear zones, some of which are of regional dimensions. For example, the Yatta shear zone, extending for over $300 \mathrm{~km}$ in a NW-SE direction, obliquely subdivides this segment into two. Cenozoic reactivation of some of the fault and shear zones is quite evident. Petrography coupled with limited geochemical analyses indicate the probable existence of Neoproterozoic island arcs in the central region of this segment. In particular, while the sequences in the northern section of the EMBS indicate an ophiolitic-midocean ridge-to island arc setting, the central section show an affinity ranging from volcanic arc-calc-alkaline volcanic arc-to within-plate volcanics setting. The southern section of the EMBS indicate a setting sequence ranging from continental shelfophiolitic sature - midocean ridge - within plate to subduction related volcanics and island arc setting. The sequences in the nothern and southern sections of the belt are interpreted to be parts of the previously deep marine "proto Mozambique ocean" prior to the protracted Mozambique orogenic event. Some of the shallow marginal zones of this ocean are likewise inferred to have been in the west, where extensive quartzite horizons are presently found. The authors strongly recommend a more enhanced multi-disciplinary study of the EMBS in Kenya.
\end{abstract}

Key words: Overview, geology, geochemistry, structures, Mozambique belt in Kenya 


\section{INTRODUCTION}

The Mozambique belt segment occurring east of the Rift System is the largest of all the four major exposed segments of this belt in Kenya (Fig. 1). This segment, referred as the Eastern Mozambique Belt Segment (EMBS) lies approximately between latitudes $3^{\circ} \mathrm{N}$ and $4^{\circ}$
$\mathrm{S}$ and longitudes $37^{\circ} \mathrm{E}$ and $39^{\circ} \mathrm{E}$. The EMBS stretches almost the full length of the country from north to south for a total distance of about $800 \mathrm{~km}$ and is about $200 \mathrm{~km}$ at its widest section. The other three segments of the Mozambique belt in Kenya are the north-west segment (NWMBS), the south-west segment (SWMBS) and the north-eastern segment (NEMBS) as shown in Fig.1.

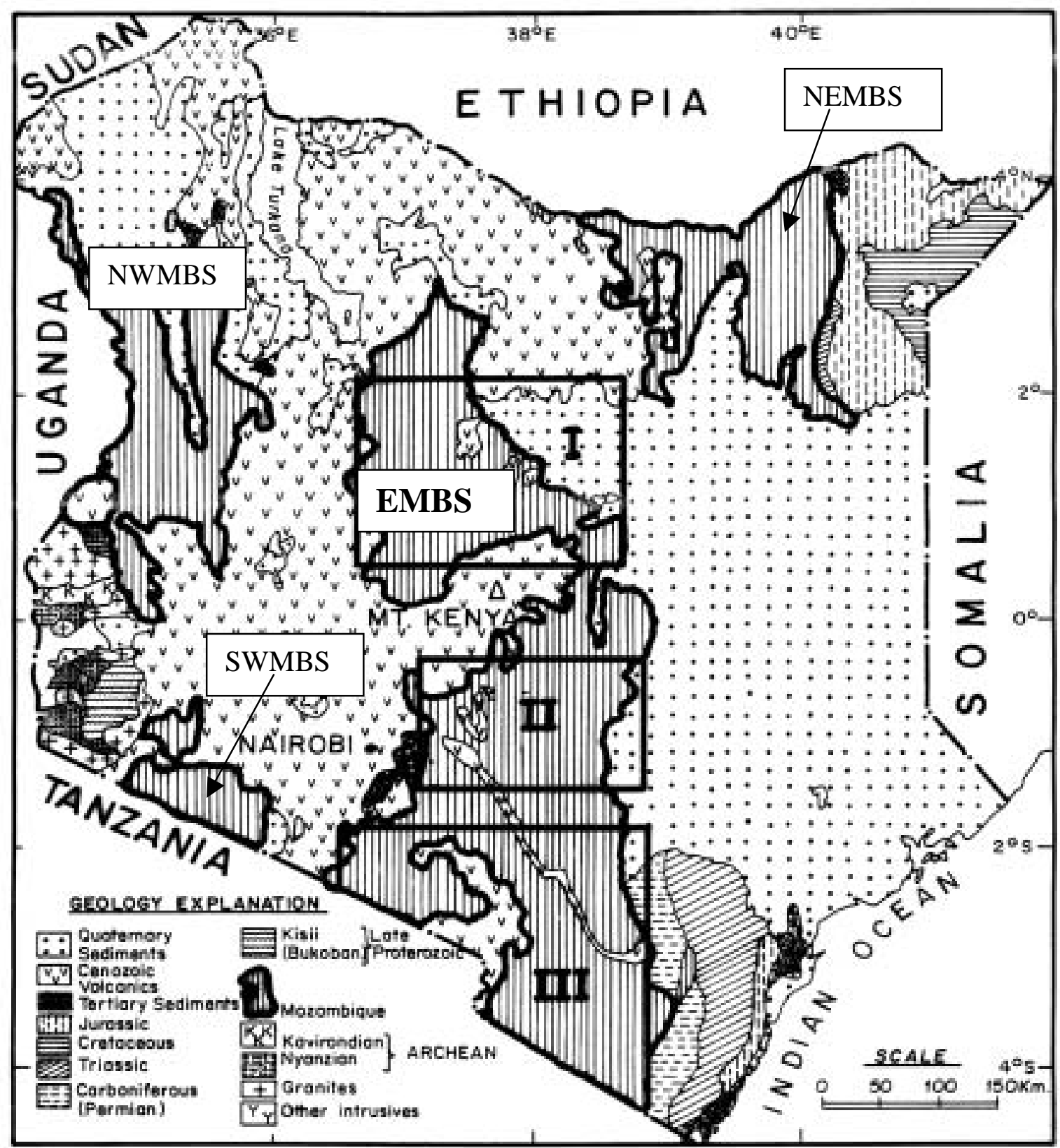

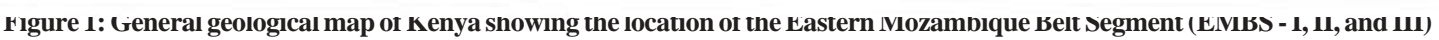


A Reappraaisal of the Geology, Geochemistry, Structures and Tectonics of the Mozambique Belt in Kenya, East of the Rift System

The initial extensive reconnaissance geological mapping carried out between 1950s and 1960s by the Geological Survey of Kenya, particularly in the EMBS, considered the Mozambique belt to be compost mostly of pelitic and semi-pelitic schists and gneisses, migmatites, granitoid gneisses, ortho-amphibolites and some units of marbles and quartzites (Bear 1952; Mason 1955; Sanders 1954, 1965; Dodson 1953, 1963; Joubert 1957; Baker 1954, 1963; Fairburn 1963; Walsh 1960; Matheson 1966; Jennings 1967; Williams 1967; and Rix 1967).

Later works in the EMBS carried out in the 1970s to 2000s have however revealed greater information pertaining to its varied geology, geochemistry, complex structures and tectonic features (Biyajima et al., 1975; Suwa et al., 1979; Opiyo-Akech and Nyambok 1984; Mathu and Tole 1984; Frisch and Pohl 1986; Key et al., 1989; Hackman et al., (1989); Mathu 1992; Mathu et al., 1991, 1994; Mosley 1993; Gaciri et al., 1993; Nyamai 1995; Baurnhoffer et al., 2000; Hauzenberger et al., 2000; and Nyamai et al., 1993, 1999, 2000a \& b, 2002).

The recently realized geological information in the country and in the regional areas (e.g., Shackleton, 1986; Key et al., 1989; Berhe 1990; Mosley 1993; Muhongo 1991, 1994, 1998; and Stern 1994) has necessitated the authors to undertake a broad overview of the Mozambique belt, particularly of the EMBS in Kenya, and hope that with more fieldwork, this may throw more light in terms of its tectonic evolution. Present knowledge on its geology, structures, tectonics and geochemistry indicates the EMBS to be occupying a major part of the continental transition zone between the low to medium grade rock assemblages of the Mozambique belt of the north and its high grade regional metamorphic assemblages of the south in Eastern Africa.

Although important high-grade tectonothermal events in the Mozambique belt have been dated between about 845 and $715 \mathrm{Ma}$ (Cahen et al., 1984; Andriessen et al., 1985; Key et al., 1989) using mainly Rb-Sr method, the more precise and reliable $\mathrm{U}-\mathrm{Pb}$ dating in the region is acutely lacking. The scarsity of reliable true isotopic ages from the Mozambique belt in Kenya precludes any meaningful interpretations on its tectonic evolution. According to Muhongo (2003) the lack of reliable isotopic data has made it difficult to evaluate the vestiges of Mesoproterozoic events/units from this part of the belt. The subsequent cooling and uplift of the basement has been traced by K-Ar dates on biotites, which range between 438 and $528 \mathrm{Ma}$ (Shibata and Suwa, 1979; Cahen et al., 1984; Frisch and Pohl, 1986). Thermobarometric PT calibrations obtained from various mineral pairs range from $5.5-7.1$ kbars and $500-750{ }^{\circ} \mathrm{C}$ (Nyamai et al., 2000b, Inoue and Suwa 1979, Suwa et al., 1979). The Mozambique belt itself has a complex history of superimposed deformation and metamorphism which consists in part of high grade reworked or reactivated basement (Muhongo, 1991). The belt has been inferred to mark the sites for several superimposed Proterozoic subduction zones and collisional sutures (Muhongo, 1998, and references therein).

It is the hope of the authors that this paper will trigger a further more concerted multi-disciplinary study of the belt in the EMBS region. This region could be carrying some key information bridging the gap between the two geologically contrasting regions of the Mozambique belt in Africa. Preliminary geological results as outlined in this paper indicate that the northern part of the EMBS is ophiolitic, the central part has an island arc affinity, and the southern part reflects shallow to deep marine rock assemblages with ophiolitic characteristics. Presented here below are the major highlights of the geology, geochemistry (where available) and structural geology of the EMBS.

\section{GEOLOGY}

The geology of the EMBS is best presented by description of its three characterizing sub-areas, namely: Sub-area I - enclosing the extreme northern part of EMBS that is located north of Mt. Kenya; Sub-area II - enclosing the central region that occurs east of Nairobi and lastly Subarea III - that encloses the southern part surrounding the Chyulu Hills (see Fig.1). Below is a summary of the geology of each sub-area. The detailed geology of each sub-area is best documented by the respective geological reports covering the respective sub-areas.

\section{Northern sub-area I of the EMBS of Kenya}

The geology of this sub-area I in the North-Central Kenya constitutes a vast exposure of the MB south of Lake Turkana in the Samburu-Marsabit area of north-central Kenya (Fig. 1). The complex geology of this region was unravelled by Key et al. (1989) in such a detail that it warrants a close examination of its tectonic features and scenario in order to gain more insight into the polyphase evolution of the MB as a whole.

The lithostratigraphy of the Samburu-Marsabit area consists of the basal Mukogodo Migmatites which are unconformably overlain by metasediments such as banded gneisses, into which the migmatites have been thrust as 
subconcordant sheets. Continental clastic units (e.g. Ndura, Loroki, Kotim gneisses) comprising metaarkoses, meta-quartzites and manganiferous sandstones, with locally preserved sedimentary structures, are among the banded gneisses. These continental units show facies change into more pelitic metasediments, the Don Dol Gneisses, in the center of the Samburu-Marsabit area. The basal metasediments are overlain by a sequence of marbles, meta-pelites and vanadiferous graphitic gneisses (Ol Doinyo, Ng'iro, Lolkoitoi, Makoni, and Il Busi Gneisses). Meta-volcanic slices, some of which are ophiolitic (Chaparkrom, Korr, Siambu Complexes), were emplaced along sub-horizontal thrusts into high tectonic levels in the meta-sedimentary pile.

The granulites of the Samburu-Marsabit area extend westward underneath the Cenozoic strata of the East African Rift Valley where the root zone of the MB was probably located. This zone corresponds to the axis of bilateral symmetry which Sanders (1965) had postulated as the one where the nappes of western Kenya face north-west and those in the eastern part of the SamburuMarsabit area face to the southeast. According to Key et al. (1989) this was the root zone of the Mozambique orogen marking the separation of the southeastward backthrust units in the east from the overthrust western units located on the external and foreland zones near the craton.

Several syn-tectonic and post-tectonic granitoid intrusives occur in the Samburu-Marsabit area. These consist of small trondhjemite sheets which are either concordant or discordant with the gneisses they intrude; low level concordant plutons; and high level discordant plutons. There are also vertical and narrow micro-granite plutons which are concordant with the foliation of the adjacent gneisses and narrow partial melt migmatite zones rimming some of the larger stocks; and common minor felsic dykes and veins of various ages. Key et al. (1989) recognized the following sequence of tectonic events in the area: First there was plate collision which caused a tectono-thermal event in the amphibolite-granulite facies at about $820 \mathrm{Ma}$, and produced major recumbent folds with ductile thrusting which interleaved the basement, meta-sedimentary cover, and slices of ophiolitic metavolcanic complexes. The first phase of this deformation involved the emplacement of crustal melt granites and metabasic dykes. Between $620 \mathrm{Ma}$ and $570 \mathrm{Ma}$ there was post-collisional greenschist-amphibolite facies deformation which produced regional uptight folds and vertical ductile strike-slip shear zones which strike subparallel to the orogenic strike. This culminated in the intrusion of syntectonic granites. High level open folding and brittle shears mark the terminal orogenic events. The final uplift and cooling has been dated at about 500 - 480 Ma. Other detailed accounts of the geology of this subarea have been documented by Randel (1970), Williams (1966), Jennings (1967), Rix (1967), Charsley (1987), Key and Rop (1987), Key et al. (1989) and Dodson (1991).

\section{Central sub-area II of the EMBS in Kenya}

The geology of this sub-area is composed of mainly mica (biotite, muscovite) and /or hornblende schists and gneisses that occasionally show the presence of staurolite, almandine garnet, kyanite and sillimanite. Present also are amphibolites ( \pm garnets), migmatites, granitoid gneisses and granites, intrusive and meta-intrusive mafic and ultramafic rocks that include diorites, gabbros, anorthosites, peridotites and picrites (Fig.2). These mafic and ultramafic rock bodies are noted especially in the region occurring north-east of Nairobi enclosed by such towns such as Thika, Machakos, Embu, Chuka and Mwingi. The ultramafic bodies in this sub-area are relatively few as compared to the occurrence of the mafic gabbroic and anorthositic bodies. Some meta-andesitic volcanic rocks of limited extent have been documented east of Thika town by Mathu and Tole (1984). More detailed geological accounts of the sub-area are well covered by the various reports and research papers documented by Baker (1954), Bear (1952), Dodson (1953), Sanders (1954), Saggerson (1957), Fairburn (1958, 1963), Biyajima et al. (1975), Nureki et al. (1977), Suwa et al. (1979), Asami et al. (1983), Mathu (1992), Mathu and Tole (1984), Mathu et al. (1991), Key et al. (1989), Hackman et al. (1989), Nyambok et al. (1993), Ochieng (1993), Mosley (1993) and Nyamai et al. (1999, 2000a \& b, 2002).

\section{Southern sub-area III of the EMBS in Kenya}

This southerly located sub-are III covering the region immediately north, north-east and east of Mount Kilimanjaro, has the Cenozoic volcanic hills of Chyulu occupying its central part. The notable sections of this sub-area with well exposed geology include the various hills in the Kajiado district and those in the Taita-Taveta district. The geology of this sub-area is to a great extent comparable to that of the northerly located sub-area I. However, it has also its own notable differences.

In southeastern Kenya the overlying Kurase-Kasigau group of metasediments shows facies change from shallow water shelf lithofacies eastward into deeper water sediments. The uppermost shelf metasediments to the east of Nairobi contain an evaporite component in the 


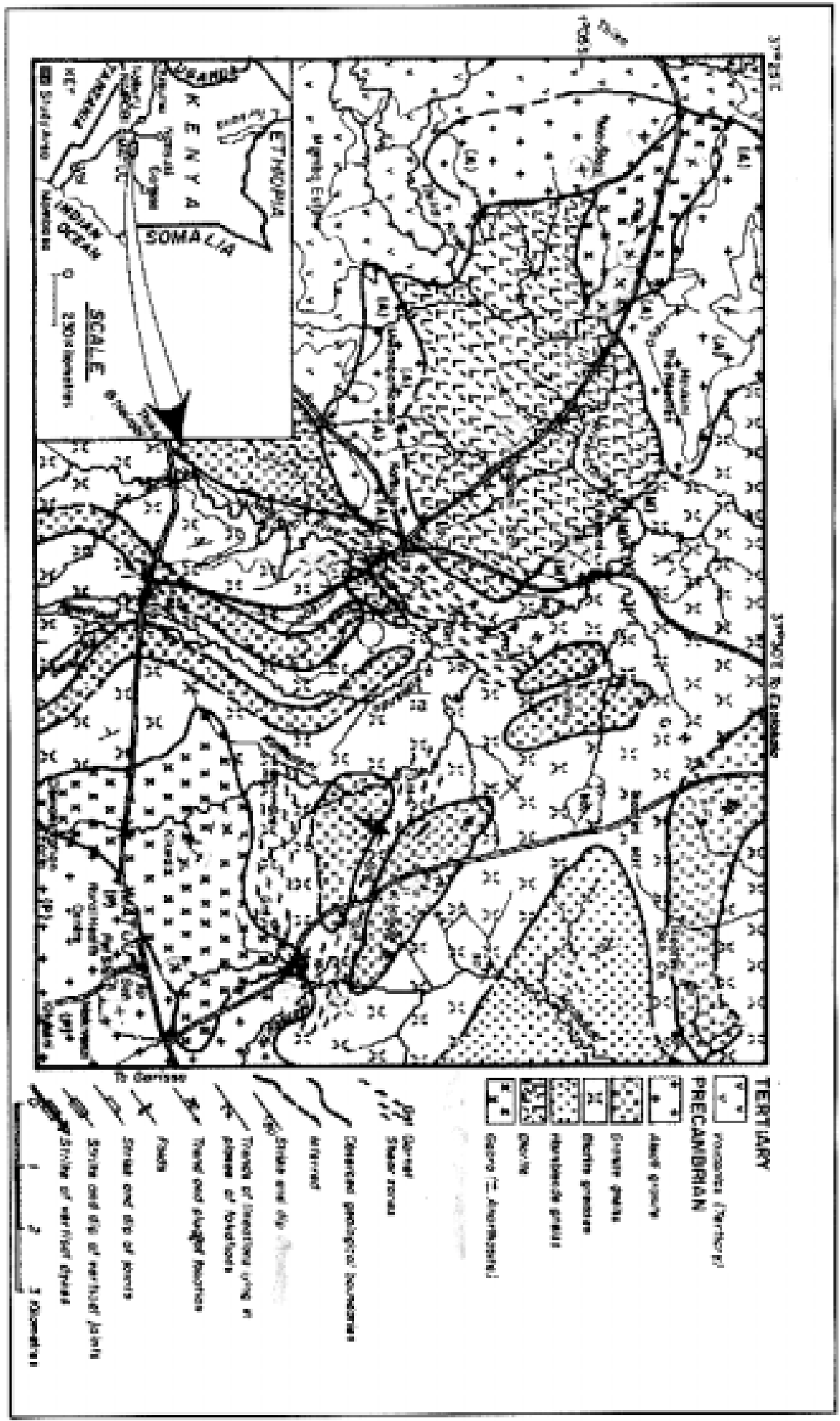

Figure 2. Geological map of Matuu-Masinga area, central Kenya (representing sub- area II of the EMBS in Fig.1) 
form of scapolite-bearing gneisses. The Kurase-Kasigau Group of metasediments occurs in the Voi-Tsavo area of southeastern Kenya as a continuation of the PareUsambara mountain terrane. The Kurase Group comprises miogeosynclinal lithologies such as marble and quartzite; and graphite, sillimanite and Kyanite-gneiss and schists; biotite-hornblende gneiss; and amphibolite (Gabert, 1984). The overlying Kasigau Group represents the eugeosynclinal facies, and consists mostly of greywackes which have been metamorphosed to quartz-feldsparbiotite-hornblende gneiss, with intercalations of orthoamphibolites. Facies transitions occur between the Kurase and Kasigau Groups; and basic and ultrabasic rocks were emplaced along regional faults or thrust zones.

Three phases of deformation have been recognized in the Kurase and Kasigau Groups, the last of which controlled the emplacement of late pegmatites and the joint pattern in this region (Gabert, 1984). Isoclinal and open folds with NNE and NNW striking axes are prevalent in the Kurase and Kasigau Groups. Although the succession of geologic events was not clearly defined, Gabert (1984) outlined the late phases of the geological history of the Kurase-Kasigau area as comprising: Barrovian medium- to high-grade metamorphism; hydrothermal activity leading to syngenetic base metal mineralization; pegmatite emplacement; and widespread resetting of radiometric ages during Pan-African tectonism at about $550 \mathrm{Ma}$..

Unlike in sub-area II, there is the notable absence of mafic and intermediate rock bodies such as the gabbros, anorthosites and diorites.. Spectacularly notable however, are the narrow north-south elongated marble units found in the westerly located Kajiado district as well as in the easterly located Taita-Taveta district in this sub-area III. It is likely that these marble units are tectonically related as discussed later in this paper. Wollastonite, which form pockets in the sub-area, is one of the economic minerals particularly in Kajiado district (Saltikoff et al., 1991). More detailed accounts of this sub-area are well documented by Walsh (1960, 1969), Joubert (1957), Weiss (1959), Saggerson (1962, 1963), Matheson (1966), Pohl and Niedermayr (1979), Horkel et al. (1979), Pohl and Horkel (1980), Prochaska and Pohl (1984), Gabert (1984), Key and Ochieng (1991), and Simonet et al. (2002).

\section{GEOCHEMISTRY}

\section{Northern sub-area I of the EMBS in Kenya}

The internal zone of the Mozambique belt in sub-area I contains imbricate slices of mafic and ultramafic rocks whose ophiolitic nature has survived high grade metamorphism and intense deformation in the mobile zone. Although these ophiolitic rocks have been widely reported by several previous authors (e.g. Kazmin et al., 1978; Prochaska and Pohl, 1984; Shackleton, 1986; Vearncombe, 1983), Berhe (1990) has added more geochemical and structural data which have further elucidated their geodynamic significance.

The Siambu complex at Baragoi is one of several ophiolitic complexes that occur in the high-grade rocks of the Samburu-Marsabit area in north-central Kenya. The Baragoi ophiolite includes metamorphosed mantle derived dunites and sheeted dykes with trace elements showing a transition between mid-ocean ridge basalts and island-arc tholeiites. Evidence presented by Berhe (1990) as indications of an ophiolitic origin for the Baragoi complex includes high chrome/low titanium values, and a MORB-normalized spider-gram (Fig. 3) for the Baragoi amphibolites that is similar to an average Marianas island-arc lava (boninitic), with low abundance's of incompatible elements and depletion in HFSE and REE, but with much higher Cr values than the Marianas lava. Discriminant diagrams such as $\mathrm{Zr} / \mathrm{Y}-\mathrm{Zr}$ (Pearce and Norry, 1979) (Fig. 4) and Ti-Zr-Y plots (Fig.5) show the Baragoi amphibolite data overlapping the fields of mid-ocean ridge basalt (MORB) and islandarc tholeiites (IAT) defined by Pearce and Cann (1973) and Pearce (1982). Modern analogues of these volcanic rocks are situated near destructive plate margins in an island arc setting (Pearce, 1982).

\section{Central Sub-area II of the EMBS in Kenya}

Analyzed representative granitic samples from the central Sub-area II of the belt occurring in Matuu-Masinga area, central Kenya, have been reported by Nyamai et al. (1999). Reported data from analyzed trace element (Y, $\mathrm{Nb}, \mathrm{Rb}$ ) versus $\mathrm{SiO} 2$ discriminant diagrams for these rocks (Fig. 6) indicate an apparent bias to that of volcanic arc affinities. A plot of $\mathrm{Rb}$ versus $(\mathrm{Y}+\mathrm{Nb})$ in Figure 7 show a characteristic tendency from calc-alkaline volcanic arc to within-plate affinities. 


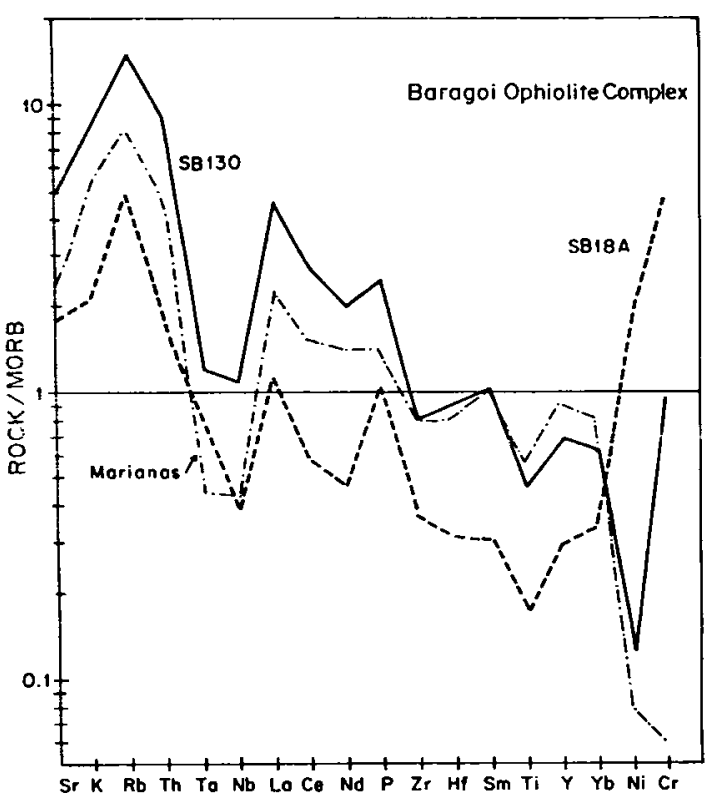

Figure 3. Representative geochemical patterns for the Baragoi lavas. Hornblende plagioclase gneiss (SB 130); amphibolite (SB 18A). Normalising values taken from Pearce (1982). The Baragoi lavas are compared with an average Marianas island arc lava (Hole et al., 1984). (Redrawn from Berhe, 1990).

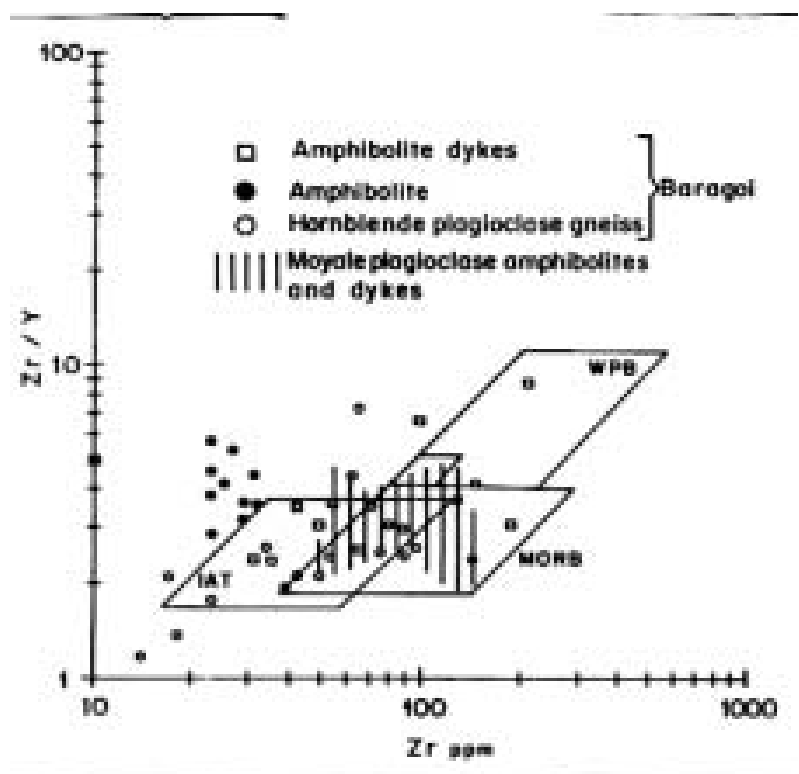

Figure 4. $\mathrm{Zr} / \mathrm{Y}$ versus $\mathrm{Zr}$ discrimination diagram for basic rocks of Baragoi and Moyale ophiolite zones. Discriminant fields taken from Pearce and Norry (1979). (Modified after Berhe, 1990)

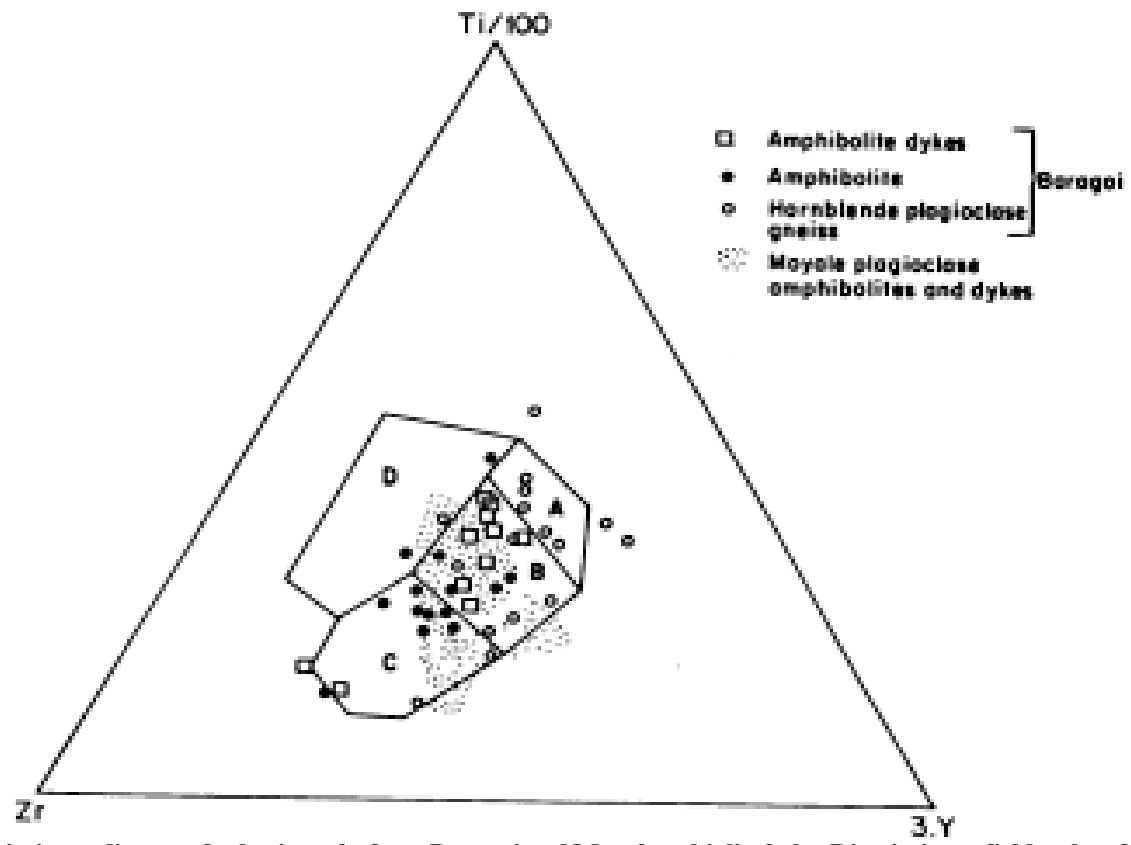

Figure 5. Ti-Zr-Y discriminant diagram for basic rocks from Baragoi and Moyale ophiolite belts. Discriminant fields taken from Pearce and Cann (1973). Ocean island or continental basalt plot in field D; Ocean-floor basalts in field B; low-potassium tholeiites in fields A \& B; calcalkali basalts in fields $\mathbf{C} \& \mathbf{B}$. 


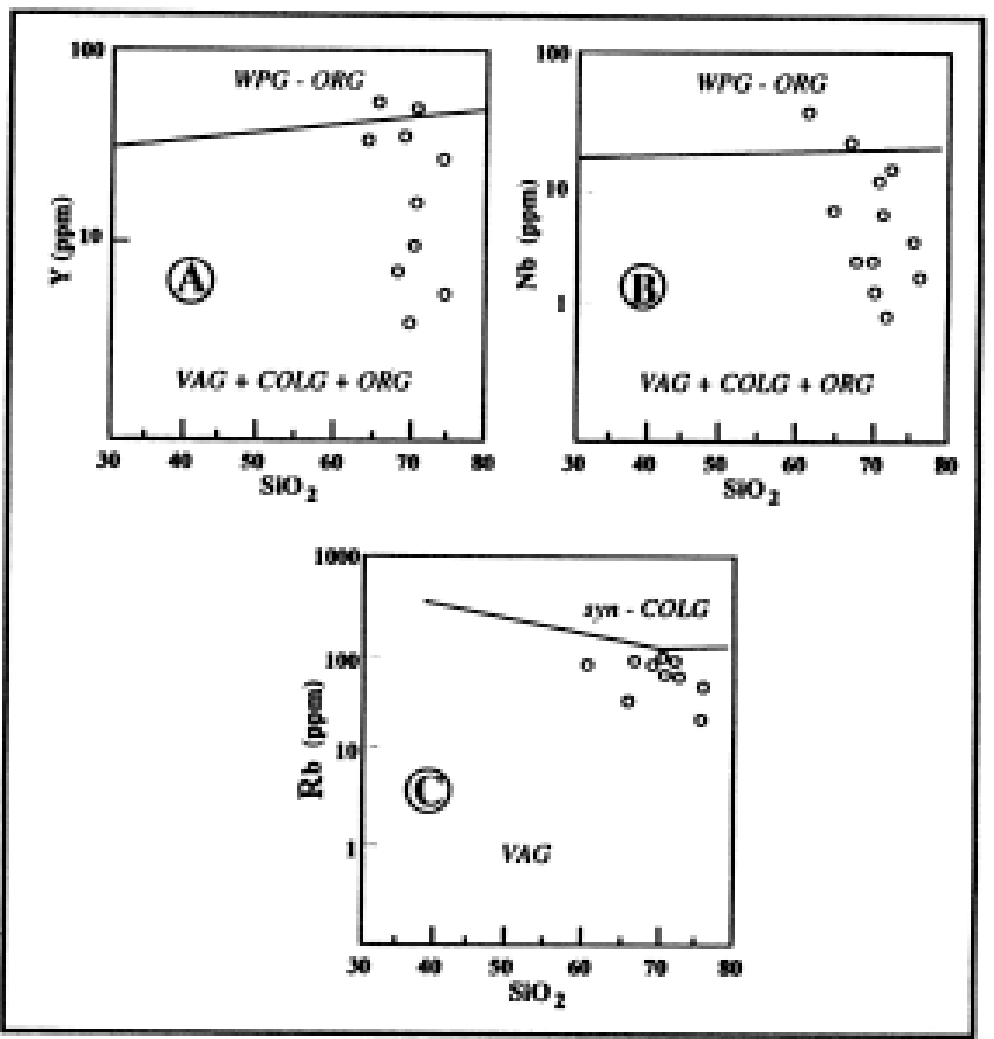

Figure 6. $\mathrm{SiO}_{2}$ variation diagram for $\mathrm{Rb}, \mathrm{Nb}$, and $\mathrm{Y}$ on the granitic rocks of the Matuu-Masinga area (representing sub-area II in Fig.1) discriminating between the various tectonic environments. VAG - Volcanic arc granite, syn-COLG - syn Collision granite, ORG - Orogenic granite, WPG - Within plate granite. (Diagrams after Pearce et al., 1984)

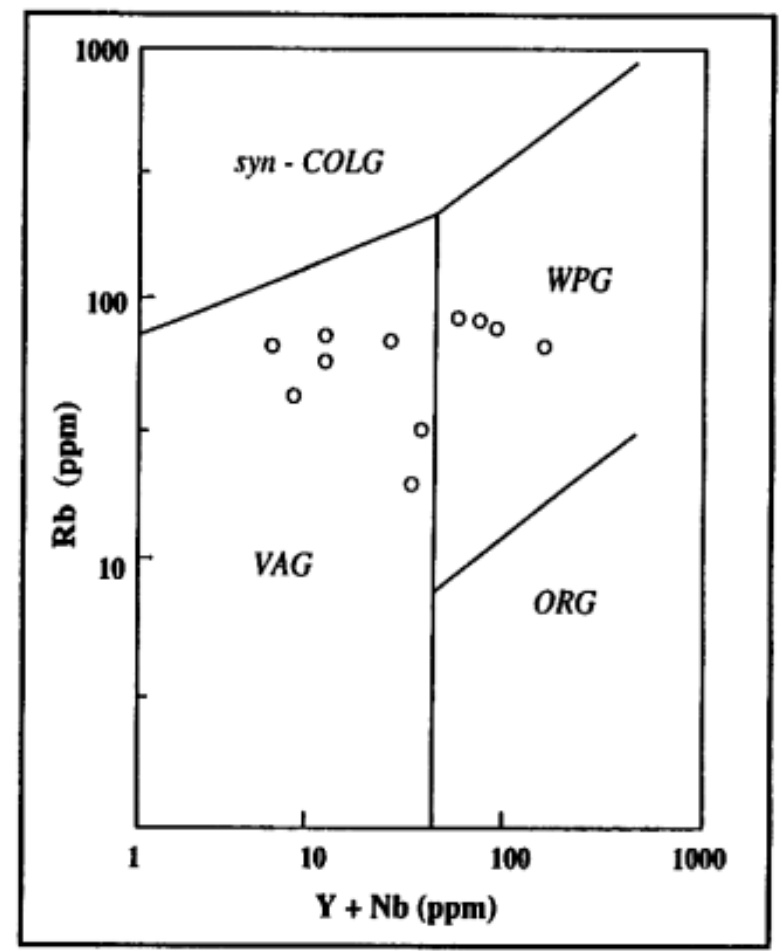

Figure 7. $\mathbf{R b}-\mathrm{Y}+\mathrm{Nb}$ variation diagram for the granitic rocks of Matuu-Masinga area, central Kenya (representing sub-area II in Fig.1), discriminating between the various tectonic environments (Diagram after Pearce et al., 1984). 


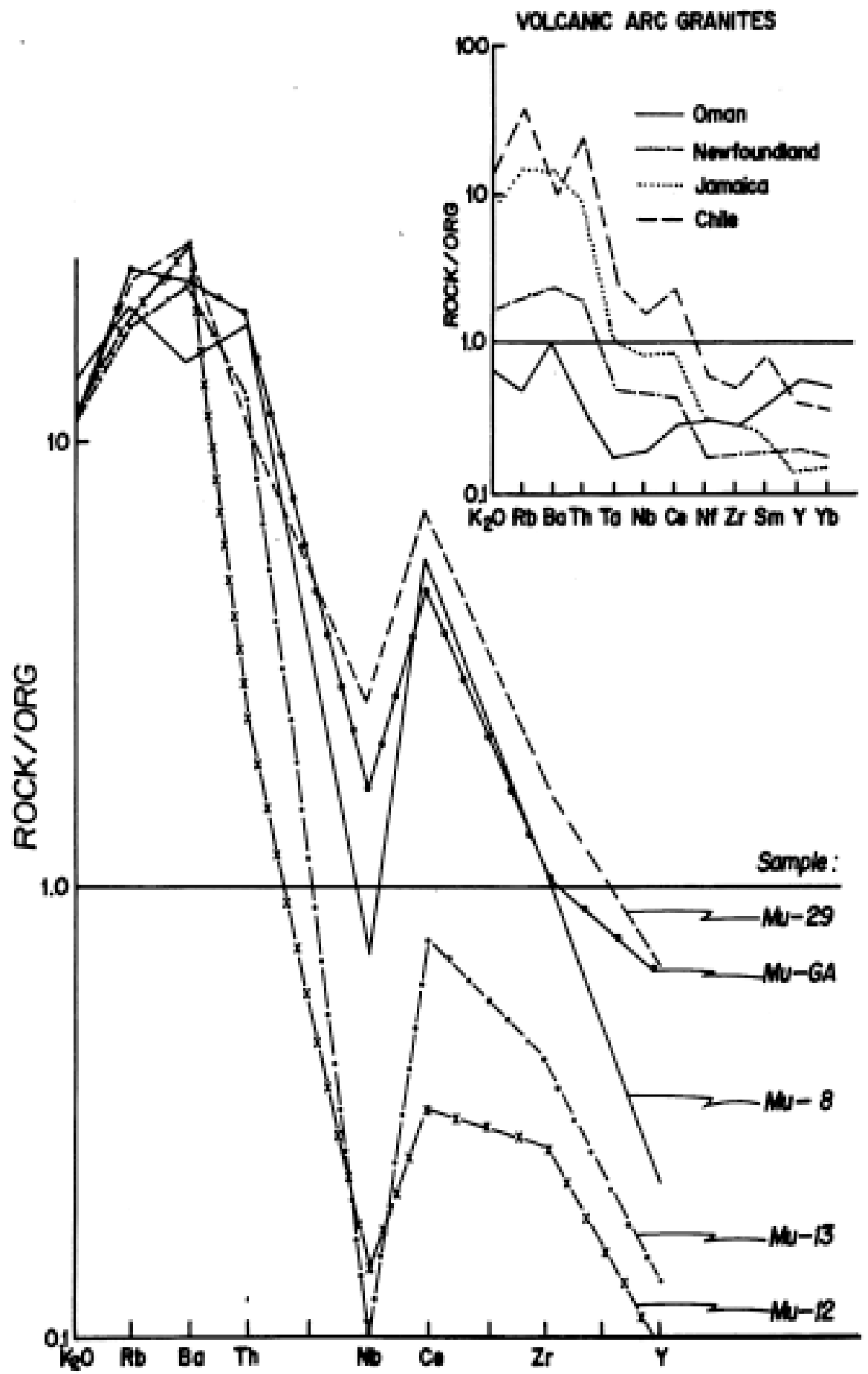

Figure 8 Ocean ridge granite (ORG) normalized patterns for some granitic rocks from Matuu-Masinga area, central Kenya. Inset shows some representative volcanic arc granite patterns (after Pearce et al., 1984). (Diagram after Nyamai et al., 1999). 
The patterns of five granitic rocks from Matuu-Masinga area (Fig.8) demonstrates that there is a relative enrichment in large ion lithophile (LIL) elements $(\mathrm{Rb}, \mathrm{Sr}$, and $\mathrm{K}$ ) over the other incompatible elements $(\mathrm{Nb}, \mathrm{P}, \mathrm{Zr}$, $\mathrm{Ti}$, and $\mathrm{Y}$ ). This feature is commonly apparent in volcanic arc granites that are normally characterized by enrichments in $\mathrm{K}, \mathrm{Rb}, \mathrm{Ba}$, Th (typical in calc-alkaline series) and Ce relative to $\mathrm{Nb}, \mathrm{Zr}$ and $\mathrm{Y}$.

\section{Southern Sub-area III of the EMBS in Kenya}

The southern sub-area III of the EMBS is best represented by the Mtito Andei-Mwatate area in SE Kenya. A lower Kurase unit, which is a shelf sequence rich in carbonates, is separated from the overlying Kasigau unit, a monotonous sequence of metagreywackes and meta-volcanics (possibly intruded by diorites), by an ophiolitic suture, the Voi Suture Zone (Pohl and Horkel, 1980) (see Fig. 9).

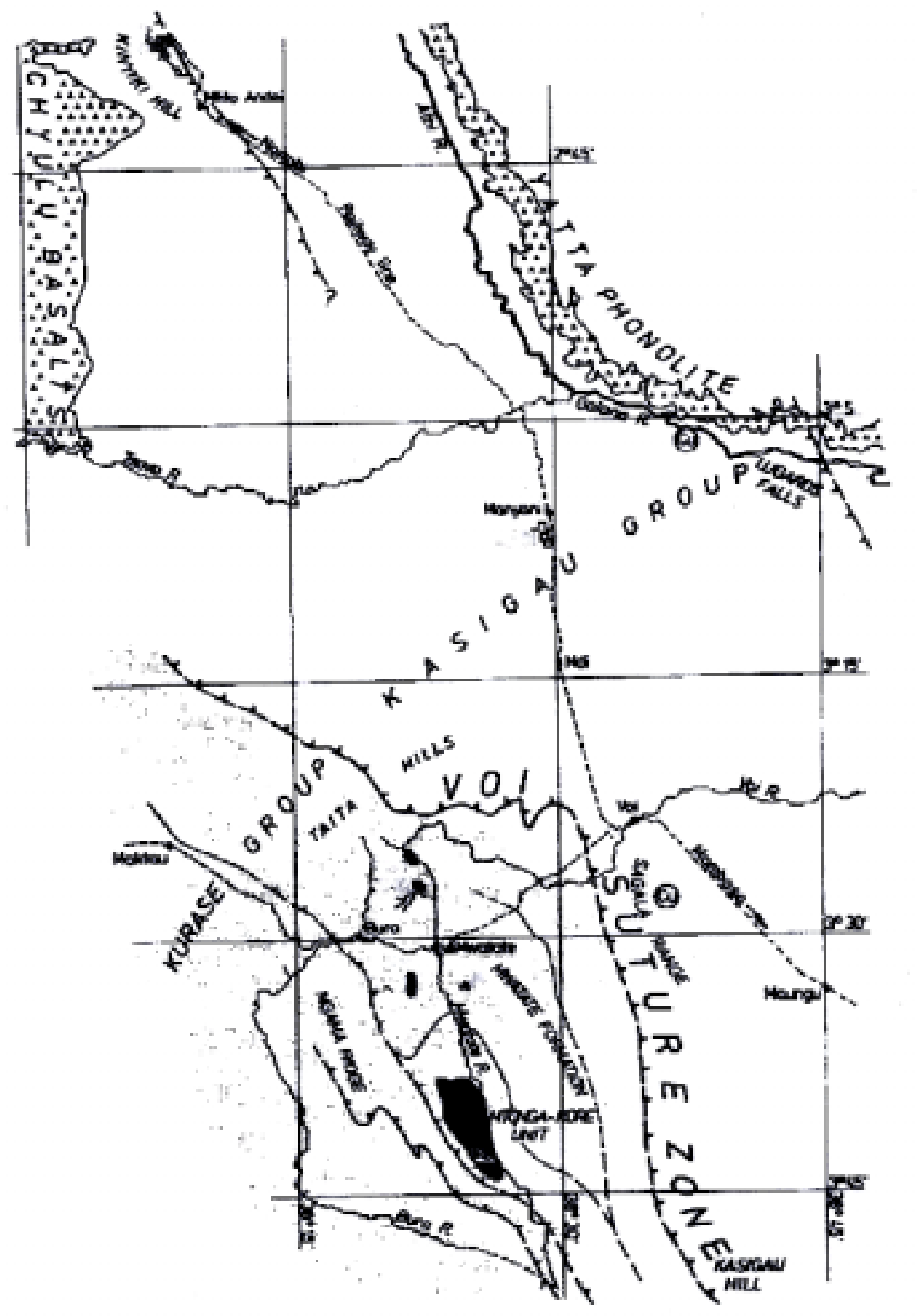

Figure 9. Tectonic sketch map of the Mtito Andei - Taita Hills area (Redrawn after Frisch and Pohl, 1986). 
A Reappraaisal of the Geology, Geochemistry, Structures and Tectonics of the

Mozambique Belt in Kenya, East of the Rift System

The Kinyiki Hill rocks occurring near Mtito Andei are considered to represent part of an ophiolitic suite (Frisch and Pohl, 1986). This can be affirmed by the rock association and the chemical composition despite of partly strong alteration by metamorphic reactions. The rock suite consists of dunites- interpreted as altered ophiolite metamorphic peridotites, gabbroic cumulates - that usually occur in the lower section of ophiolitic crustal sequence, and $\mathrm{N}$-type mid-ocean ridge basalts which represent the normal type of tholeiitic basalts produced at mid-ocean ridges (see Figs. 10-12). These sequences support that true oceanic crust and upper mantle has been dismembered, tectonized, and metamorphosed under high-grade conditions. Similar rocks crop out along other thrusts and along the main suture zone through-out the Taita Hills.

Amphibolites of the Mwatate Formation, being part of the Kurase Group, reveal the characteristics of withinplate tholeiites or transitional within-plate tholeiites (see Figs.10-12) as they occur at continental margins near spreading centres. Both modes of formation are in good accordance with the geological situation. The meta-basalts belong to a continental shelf sequence, and transitional or continental tholeiites are characteristic of such an environment not long after successful rifting led to the opening of an ocean.

Amphibolites from the Kasigau Group support the field interpretation that this group consists mainly of subduction-related volcanics and their clastic derivatives in an island arc or active continental margin setting (Frisch and Pohl, 1986). In the $\mathrm{TiO}_{2}-\mathrm{Zr}$ diagram after Pearce et al. (1981) they discriminate as primitive arc lavas (Fig. 10B). However for definite conclusion, further geochemical studies are required.

\section{STRUCTURES AND TECTONICS}

Structural and tectonic features of the EMBS in Kenya are complex on all scales with superposed folds, thrusts with imbricate structures to high angle reverse faults, shear zones, pegmatites and veins of at least three generations (Fig.13).
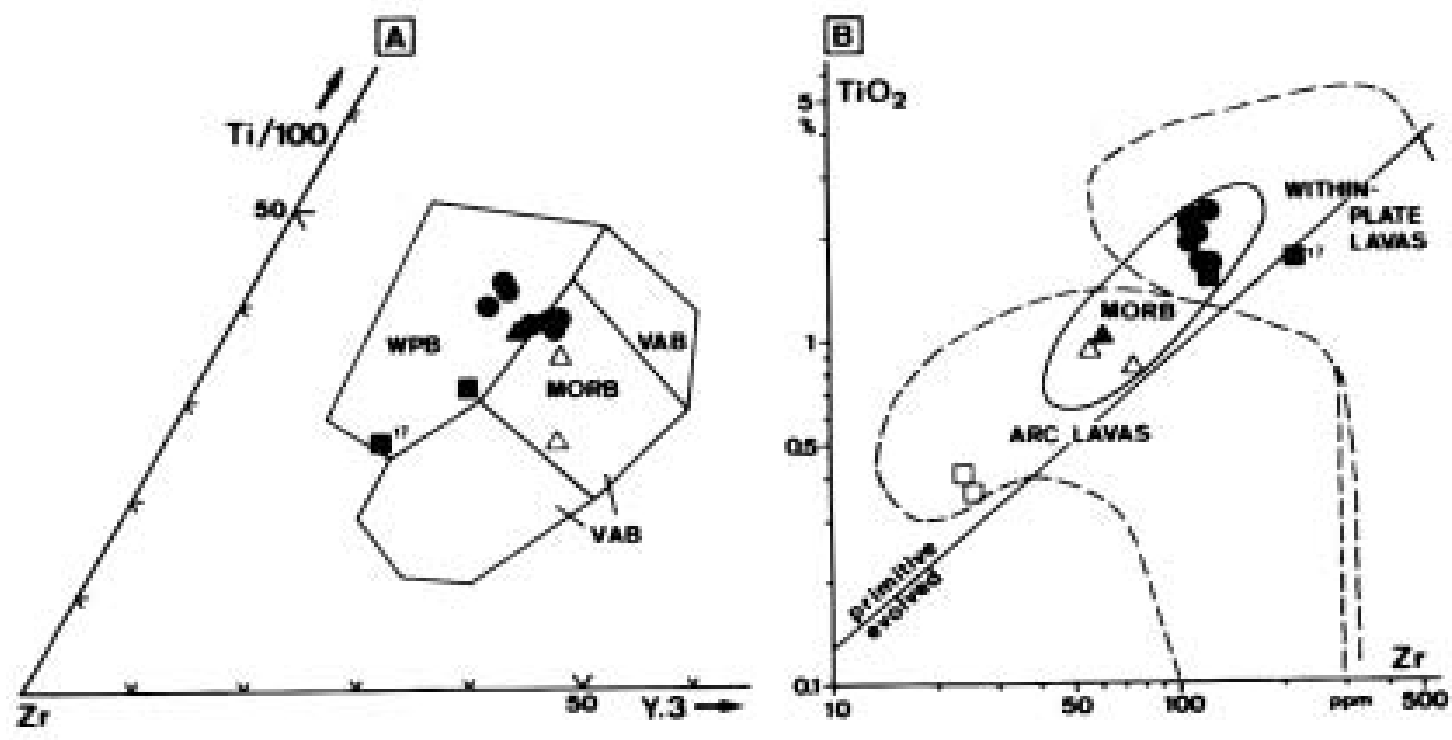

Figure 10. Discriminant diagrams after Pearce and Cann 1973 (A), and Pearce et al.1981 (B), for the amphibolites from Mtito Andei-Mwatate area. WPB, within-plate basalt; VAB, volcanic arc basalt; MORB, mid-oceanic ridge basalt. Full symbols: amphibolites from the Mwatate area, Mwatate Formation, Kurase Group. Open triangles: amphibolites from the basic-ultrabasic association, Mtito Andei thrust zone. Open quadrangles: amphibolites from the Kasigau Group. (Diagrams redrawn from Frisch and Pohl, 1986). 


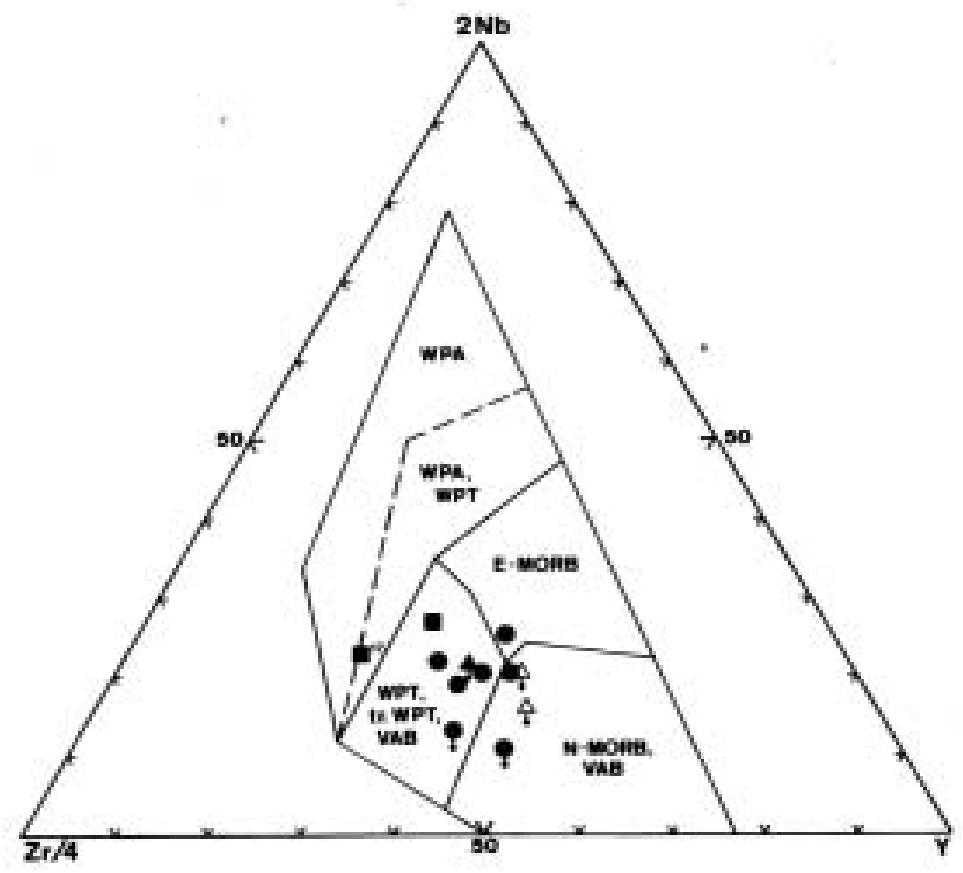

Figure 11. Discriminant diagram (after Meschede in Frisch and Pohl, 1986) for amphibolites from Mtito Andei-Mwatate area. WPA, WPT, within plate alkalic and tholeiitic basalt; tr. WPT, transitional within-plate tholeiite. Other abbreviations as in Fig.10. MORB's are subdivided into N-and E-type. Symbols as in Fig. 10.

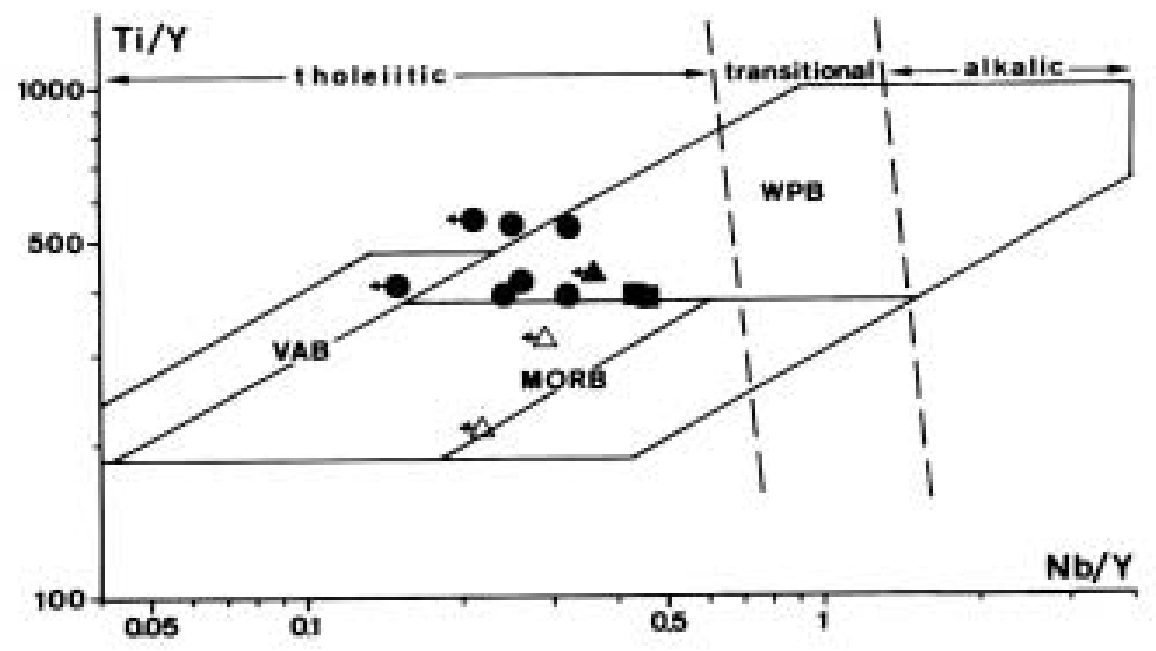

Figure 12. Discriminant diagram (after Pearce 1982, 1983) for the amphibolites of Mtito Andei-Mwatate area, south-east Kenya. Abbreviations and symbols as in diagram Figs. 10 \& 11. 


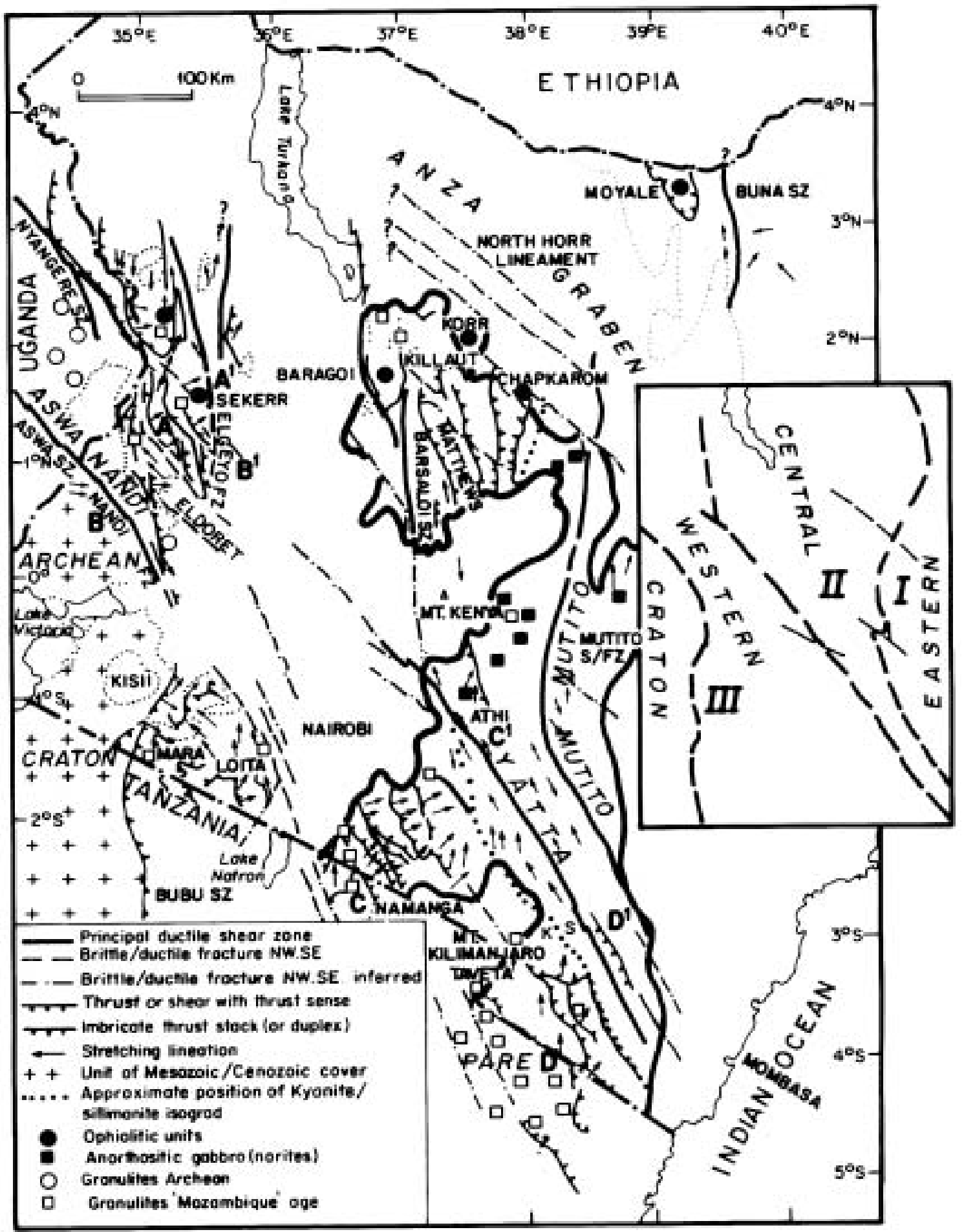

Figure 13. Principal Proterozoic structures in Kenya. (Redrawn after Mosley, 1993) 


\section{Folds}

Major folds in the EMBS with axial traces of tens of kilometers in length are common in all three sub-areas. Similarly common are mesoscopic (outcrop scale) as well as minor to microscopic folds. At least three fold generations have been widely distinguished in various sections of the EMBS, e.g., in the southern sub-area III by Pohl and Niedermayr (1979), Weiss (1959), Gabert (1984), Horkel at al. (1979) and Mathu et al. (1994); in the central section by Mathu and Tole (1984), Mosley (1993) and Nyamai et al. (1999); and in the northern subarea III by Williams (1966), Dodson (1963, 1991), Baker (1963), Vearncombe (1983), and Key et al. (1989). Because of the intense deformation, early folds have occasionally become rootless intrafolial folds. The second generation folds are the most pronounced often forming the regional folds while the laiter folds are gentle open warps.

In the central sub-area II, for example between Thika and Machakos towns, the superposed folds have formed elliptical to refolded structural domes and basins (Baker 1954; Biyajima et al., 1975; Miyakawa and Suwa 1979; Miyake and Suwa 1981; Shiozaki, 1983) whose cores are interpreted to be the sites occupied by granites and granitoid circular domes (see Fig. 14). In the northern subarea I, such structural domes and basins have been documented by Williams (1966) and Baker (1963).

In Kitui, which is the eastern part of the central sub-area II, major domes and basins are no longer present. However, there are major antiformal and synformal which are oriented approximately north-south but with curved axial traces because of refolding (Fig. 15). The Kitui anticline for example, has a north-south axial trace extending for approximately $200 \mathrm{~km}$ and its limbs extending about 30 $\mathrm{km}$ each on either side of its axial trace. It is a major antiform in the eastern part of sub-area II (see Sanders (1954), Bear (1952), Saggerson (1957), Crowther (1957), Mathu (1992), Mathu and Tole (1984). The sinous trend of its axial trace reflects the effects of refolding on this Kitui antiform. In the northern sub-area I, superposed folds have been well documented by Vearncombe (1983), Key et al. (1989), Baker (1963), Williams (1966), and Jennings (1967). Williams (1966), for example, has presented a series of structural domes and basins in the Chanler's Falls area of this northern sub-area I.

In the southern sub-area III, complex superposed folds have been well documented by Joubert (1957), Weiss (1959), Matheson (1966), Pohl and Niedermayr (1979), Horkel et al. (1979) and Mathu et al. (1994).

\section{Lineations, thrust faults and shear zones}

The EMBS has been heavily segmented into a number of structural or tectonic units, both of small and large scale, by several thrust faults and shear zones (Figure 13). Mosley (1993), Nyambok et al. (1993) and Mathu (1992) have shown that the Mutito Fault and Shear Zone (MFSH) and its south-westerly located Yatta Shear Zone (YSZ), the two major tectonic features of regional dimensions, have segmented the EMBS into three clearly distinct tectonic domains. Both the MFSZ and the YSZ extend for a number of hundreds of kilometers in length (Figure 13). The three tectonic domains can be referred to as the Eastern, the Central and the Western domain (Figure 13). However, studies in the major geological disciplines such as field mapping, structural geology, geochemistry, stratigraphy and geochronology have not yet been carried out adequately to support these three tectonic domain subdivision of the EMBS.

Lineations and linear structures are greatly influenced by the YSZ and MFSZ into three tectonic domains. For example, in the Eastern and the Central domains the lineations are north-west to north-south oriented parallel to the YSZ or the MFSZ (Mosley, 1993). In the western domain, particularly in the Kajiado area, the lineations have a plunge mainly in the north-east (Matheson 1966, Shackleton 1986, and Mosley 1993). It has been postulated that the lineation and linear structural trends particularly those oriented in the north-south and northwest-southeast are due to escape of strain in the Mozambique belt rocks as a result of rigid craton collision to the west (Mosley, 1993, Shackleton 1986). However, at the moment no regional modeling of lineations and linear structures has been exhaustively carried out.

Thrust faults are quite pronounced in the northern subarea I where they trend almost north-south. The thrusts are relatively fewer in the central sub-area II and reappear again in abundance in the southern sub-area III where they trend from north-west to south-east. The sense of thrust is either easterly or westerly in both the sub-area I and sub-area III. Occasionally imbricate thrust stacking is present in the two sub-areas.

\section{Pegmatites and Veins}

Pegmatites and veins of at least three different generations are notably present in the EMBS. These are notably composed of quartzo-feldspathic minerals with 


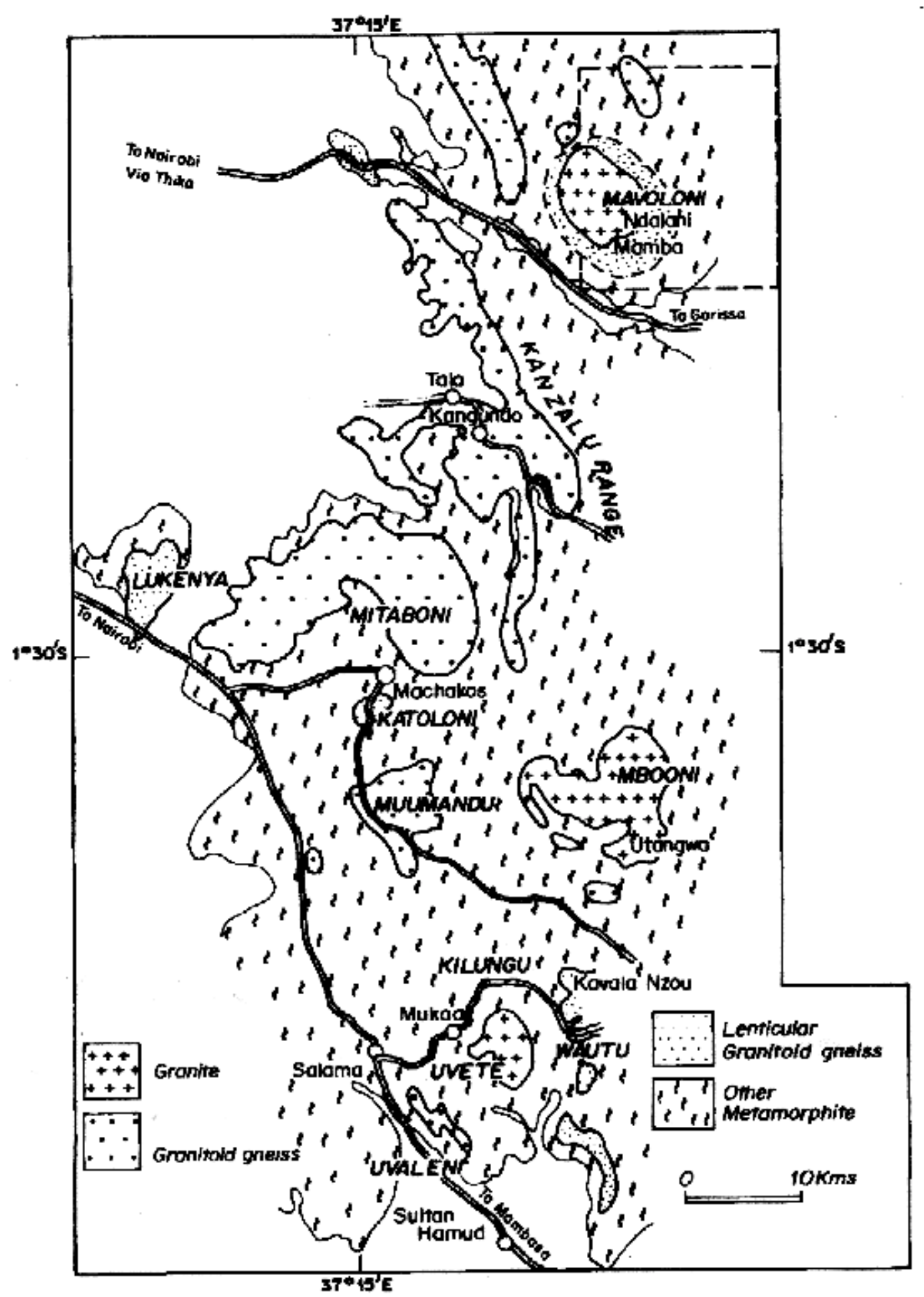

Figure 14 Locality map showing the distribution of the granite and granitoid gneiss in the sub area II (see Fig.1) of the Eastern Mozambique belt segment (EMBS), Machakos, Kenya. (Map modified after Baker 1954, Fairburn 1963, Biyajima et al. 1975, and Miyakawa and Suwa 1979). 


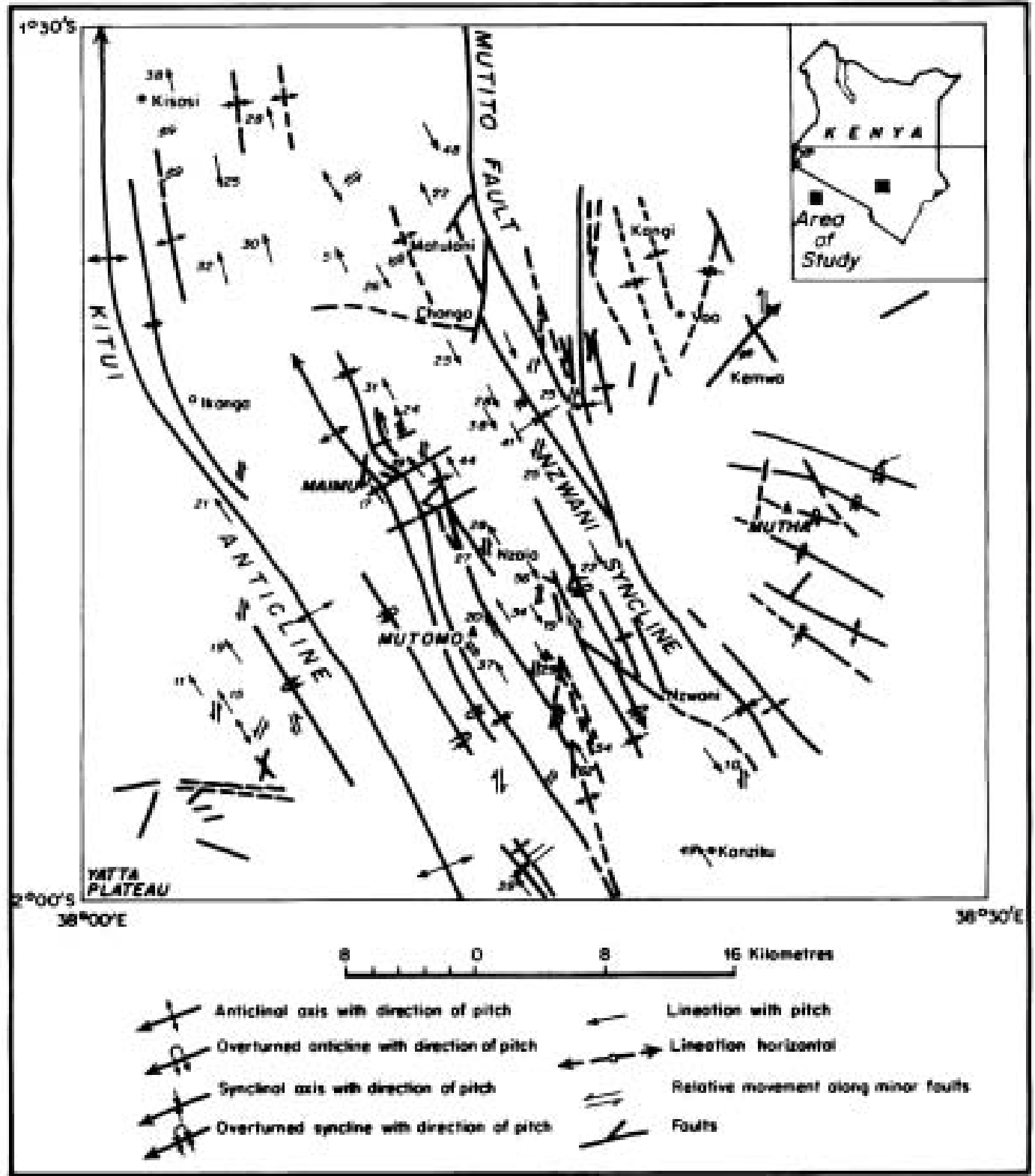

Figure 15 Structural map of the South Kitui area (Map modified after Saggerson, 1957) 
few micas, particularly biotite. They vary in size from several meters thick for the pegmatites to a few millimeters thick for the veins. The earliest pegmatites and veins are folded and boudinaged while the youngest are least deformed and largely are composed of pink potash feldspars.

\section{DISCUSSION AND CONCLUSIONS}

The Mozambique belt as exposed in Kenya occurs in four major segments, two to the west and two to the east of the Rift System (Figure 1). The two segments to the west of the rift have been referred to as the north-western Mozambique Belt segment (NWMBS) and the southwestern Mozambique Belt segment (SWMBS) respectively. The other two segments occurring to the east of the Rift System are the north-eastern segment (NEMBS) and the eastern segment (EMBS). The EMBS forms the main focus of this paper.

Based on various geological aspects, the EMBS has been subdivided and described under three sub-areas: the northern sub-area I, the central sub-area II, and the southern sub-area III. Geology, structures and tectonics and some geochemical studies have revealed that the sub-area I has ophiolitic rock assemblages. Such ophiolitic rock assemblages have an NW-SE trend that as been realized from the documented works by Vearncombe (1983), Shackleton (1986), Berhe (1990), Mosley (1993), Stern (1994) and Key et al. (1989).

The central sub-area II show a major geological change from that of sub-area I. Its geology is dominated by diorites, gabbros, anorthosites, granites, few andesites and ultramafic rocks, and metamorphic rocks - gneisses, schists and amphibolites. This central section show an affinity ranging from volcanic arc- calc-alkaline volcanic arc- to within-plate volcanics setting. The whole suite is more indicative of a region of island arc rock assemblages. Preliminary geochemical data realized recently have given support to this island arc postulation for the tectonic origin of these rock assemblages (Mathu and Tole 1984; Mathu et al. 1991; and Nyamai et al. 1999). Abdeen et al. (2000) has documented similar rock assemblages of island arc regime along strike in southern Egypt.

In the southern sub-area III, a north-west to south-east geotraverse that joins this sub-area with SWMBS shows that the original rock sequence along this geotraverse from the west graded from shallow shelf arenaceous sediments - which metamorphosed to quartzites in SWMBS- to deep marine sediments, presumably ophiolites, eastwards in sub-area III, particularly in the Taita
Hills. In the Taita Hills, these deep marine metamorphic rock sequences are characterized by thick marble bands, pelitic schists and gneisses of original argillaceous nature prior to regional metamorphism. Highly metamorphosed ultramafic rocks are dominated by anthophyllite. Although satisfactory geological mapping has been carried out in this southern sub-area III, adequate geochemical investigations are still lacking for proper categorization of these rocks. Thrusting, including imbricate thrusts that are associated with ultramafic rocks, are quite pronounced in Taita Hills. The elongate marble units occurring to the west in Kajiado district and their comparative units in the Taita Hills have been suggested to be related through nappe folding (Mathu et al. 1991). Baurnhoffer et al. (2000) and Hauzenberger (2000) have given more detailed accounts of the tectonometamorphic geology of the Taita Hills. It is the view of the authors and that of Stern (2000) that it is only through a multidisciplinary study of the EMBS that will bridge the gap in understanding of the transitional geology of the northern and southern parts of the Mozambique belt.

The EMBS show superposed circular to elliptical dome and basin structures with granitoid gneiss cores on the western half of the central sub-area II. The eastern half of this sub-area however has NW-SE to N-S axially trending major folds that includes the Kitui antiform described earlier in this paper. Although adequate structural geological investigations have not been carried out to expound on the causes of these two contrasting tectonic fold patterns in this sub-area, this paper postulates that the Yatta Shear Zone (YSZ) could be the cause as well as the dividing tectonic boundary between them. The lateral tectonic displacements parallel to its length caused by the YSZ movements could have juxtaposed these two different tectonic fold patterns to explain their current differences across the YSZ. Such an interpretation is also inferable in the publication by Nyambok et al. (1993).

In conclusion, the following are the major highlights of the EMBS:

1. The Eastern Mozambique Belt Segment (EMBS) in Kenya, located east of the Rift System is the largest of the four exposed segments of the Mozambique belt in the country. It stretches almost the full length of the country for a total distance of about $800 \mathrm{~km}$ and a width of about $200 \mathrm{~km}$ at the widest section in the south. It is bounded between $3^{\circ} \mathrm{N}$ and $4^{\circ} \mathrm{S}$ latitudes and between $37^{\circ} \mathrm{E}$ and $39^{\circ} \mathrm{E}$ longitudes. 
2. The geology and structures from the north to the south are complex. However, based on both the geology and structures, the EMBS can be broadly sub-divided into three sub-areas: the northern subarea I, the central sub-area II, and the southern subarea III.

3. The northern sub-area I is characterized by marbles, quartzites, pelitic schists and gneisses, granulites, migmatites, extensive mafic and ultramafic rocks and pronounced thrusts that include imbricate thrust faults.

4. The central sub-area II of the EMBS, located east of Nairobi, is constituted of gneisses, migmatites, diorites, gabbros, anorthosites, granites, limited andesitic volcanics and ultramafic bodies. The area has dome and basin shaped superposed folds. Major refolded and elongated antiform and synform structures are separated from the domes and basins by the Yatta Shear Zone (YSZ). The entire lithotectonic assemblage of this sub-area is interpreted to be indicative of island arc rock assemblages.

5. In the southern sub-area III, the geology and structures are fairly comparable to that of the northern sub-area I. Marbles, quartzites, migmatites, pelitic schists and gneisses, metamorphosed ultramafic rocks, thrusts that include imbricate thrusts have all been documented. The lithotectonic assemblage of this sub-area is indicative of original shallow shelf to deep marine conditions of the Mozambique belt. The marble and quartzite units of Taita Hills could be related to those of the Kajiado district through nappe folds.

6. Geochemical studies tend to support the ophiolitic and the island arc nature of the rocks in the sub-area I and in the sub-area II respectively. However, adequate geochemical studies in the sub-area III are still lacking for proper categorization of its rocks.

The authors consider that a thorough multidisciplinary study of the EMBS in the various fields, for example extensive regional structural geological studies, organized systematic geochemical and geochronological studies, etc. would throw more light in terms of litho tectonic evolution and relationship between the Mozambique belt rocks in the north and their contemporary units in the southern portion of the Mozambique belt of East Africa.

\section{REFERENCES}

Abdeen, M.M., Abdelsalam, M.G., Dowidar, H.M. and Stern, R.J. (2000). Evolution of the Neoproterozoic Allaqi-Heiani Suture Zone, southern Egypt. Journ. Afr. Earth Sci., v. 30(4A), p.1.

Andriessen, P.A.M., Coolen, J.J.M.M.M. and Hebeda, E.H. (1985). K-Ar hornblende dating of late PanAfrican metamorphism in the Furua granulite complex of southern Tanzania. Prec. Research, v. 30, pp. 351-360.

Asami, M., Umemura, H., Tokieda, K. and Suwa, K. (1983). Mozambique metamorphic rocks in the Kilungu area, central Kenya. $8^{\text {th }}$ Prelim. Rept. Afr. Studies, Nagoya University, pp. 97-104, Japan.

Baker, B.H. (1954). Geology of the Southern Machakos area. Rep. Geol. Surv. Kenya, No.27.

Baker, B.H. (1963). Geology of the Baragoi area. Rep. Geol. Surv. Kenya, No.53, 74 pp.

Bauernhofer, A.H., Hauzenberger, C.A., Wallbrecher, E., Hoinkes, G., Fritz, H., Loizenbauer, J., Mathu, E.M., Opiyo-Akech, N. and Muhongo, S. (2000). Strain and Kinematic analysis of major tectonostratigraphical units from the Mozambique Belt of the Voi district, southeast Kenya and the Pare-Usambara Mountains, northeast Tanzania. Journ. Afr. Earth Sci., v. 30(4A), p.10.

Bear, L.M. (1952). The Geology of the area south-east of Embu. Rep. Geol. Surv. Kenya, No. 23, 45 pp.

Berhe, S.M. (1990). Ophiolites in Northeast and East Africa: implications for the Proterozoic crustal growth. Journ. Geol. Soc. London, v. 147, pp. 4157.

Biyajima, K., Suwa, K., and Miyakawa, K. (1975). Mantled gneiss dome in the Mozambique belt around Machakos area, Kenya. ${ }^{\text {st }}$ Prelim. Rept. Afr. Studies, Nagoya University, pp. 6-13, Japan.

Cahen, L., Snelling, N.J., Delhal, T. and Vail, J.R. (1984). The Geochronology and Evolution of Africa. Oxford, Clarendon Press, 512 pp.

Charsley, T.J. (1987). Geology of the Laisamis area. Rep. Mines and Geol. Dept. Kenya, No.106, 70 pp.

Crowther, A.F. (1957). Geology of the Mwingi area. Rept. Geol. Surv. Kenya, No.38.

Dodson, R.G. (1953). Geology of the North Kitui area. Rept. Geol. Surv. Kenya, No.33.

Dodson, R.G. (1963). Geology of the south Horr area. Rept. Geol. Surv. Kenya, No.60.

Dodson, R.G. (1991). Geology of the Barchuma-Kom area. Rept. Geol. Surv. Kenya, No.93, 72 pp.

EAEP Limited (1991). Philip's EAEP Atlas. EAEP, Nairobi, 136 pp. 
A Reappraaisal of the Geology, Geochemistry, Structures and Tectonics of the Mozambique Belt in Kenya, East of the Rift System

Fairburn, W.A. (1958). Geology of the Fort Hall area. Rept. Geol. Surv. Kenya, No.73, 47 pp.

Fairburn, W.A., (1963). Geology of the North MachakosThika area. Rept. Geol. Surv. Kenya, No.59, 43 pp.

Frisch, W. and Pohl, W. (1986). Petrochemistry of some mafic and ultramafic rocks from the Mozambique Belt, SE Kenya. Mitt. österr. Geol. Ges., v. 78, pp. 97-114.

Gabert, G. (1984). Structural-lithological units of Proterozoic rocks in East Africa, their base, cover and mineralisation. In: J. Klerkx and J. Michot (Eds.) African Geology, pp. 11-21. Tervunen.

Gaciri, S.J., Altherr, R., Nyamai, C.M. and Mathu, E.M. (1993). Distribution of elements in mineral pairs from Mozambique belt rocks of Matuu area, central Kenya. In: Opiyo-Akech, N., (ed.), Proceedings of the 5th Conference on the Geology of Kenya Geology for sustainable Development, pp. 57-62. UNEP/ UNESCO, Nairobi.

Hackman, B.D., Charsley, T.J., Kagasi, J., Key, R.M., Siambi, W.S. and Wilkinson, A.F. (1989). Geology of the Isiolo area. Rept. Geol. Surv. Kenya, No.103, $88 \mathrm{pp}$.

Hauzenberger, C.A., Hoinkes, G., Bauernhofer, A.H., Wallbrecher, E., Fritz, H., Thoni, M., Mathu, E.M. and Opiyo-Akech, N. (2000). Pan-African highpressure granulites, Taita Hills-Tsavo East National Park, Kenya. Journ. Afr. Earth Sci., v. 30(4A), p. 37.

Hole, M.J., Saunders, A.D., Marriner, G.F. and Tarney, J. (1984). Subduction of pelagic sediments: implications for the origin of Ce-anomalous basalts from the Marianas Islands. Journ. Geol. Soc. London, v. 141, pp. 453-472.

Horkel, A., Niedermayr, J.K., Wachira, J.K., Pohl, W., Okelo, R.E. and Nauta, W.J. (1979). Geology of the Taita Hills area. Rept. Geol. Surv. Kenya, No.102.

Inoue, H. and Suwa, K. (1979). Petrographical note on Staurolite-Kyanite-almandine pelitic gneiss occurring at the western foot of the Mbooni Hills, Machakos area, Kenya - with special reference to the $\mathrm{ZnO}$ content in Staurolite. 4th Prelim. Rept. Afr. Studies, Nagoya University, pp. 97-111, Japan.

Jennings, D.J. (1967). Geology of the Archer's Post area. Rept. Geol. Surv. Kenya, No.77.

Joubert, P. (1957). Geology of the Namanga-Bissel area. Rept. Geol. Surv. Kenya, No.77.

Kazmin, V., Shifferaw, A. and Balcha, T. (1978). The Ethiopian basement: Stratigraphy and possible manner of evolution. Geol. Rundsch., v. 67, pp. 531546.

Key, R.M. and Rop, B.K. (1987). The geology of the Marsabit area. Rept. Geol. Surv. Kenya, No.108.
Key, R.M., Charsley, J.J., Hackman, B.D., Wilkinson, A.F. and Rundie, C. (1989). Superimposed Upper Proterozoic collision-controlled orogenesis in the Mozambique belt of Kenya. Prec. Research., v. 44, pp. 197-225.

Key, R.M. and Ochieng, J. (1991). The growth of rubies in south-east Kenya. Journ. Gemmol., v. 22(8), pp. 484-496.

Mason, P. (1955). Geology of the Meru-Isiolo area. Rept. Geol. Surv. Kenya, No.31.

Matheson, F.J. (1966). Geology of the Kajiado area. Rept. Geol. Surv. Kenya, No.70.

Mathu, E.M. and Tole, M.P. (1984). Geology of the Ithanga Hills area. Journ. Afri. Earth Sci., v. 2, pp. 116.

Mathu, E.M., Ngecu, W.M., Nyamai, C.M. and Davies, T.C. (1991). Proterozoic island tectonism in the Kenyan Mozambique belt east of Nairobi. In: Muhongo, S (Ed.) Proceedings of the International Geological Field conference on the Mozambique belt in East Africa, Tanzania. UNESCO, Newslett., v. 8, p.59

Mathu, E.M. (1992). The Mutito and Ikoo faults in the Pan-African Mozambique Belt, eastern Kenya. In: Mason, R. (Ed.) Basement Tectonics. pp. 61-69. Kluwer Academic Publishers, Netherlands.

Mathu, E.M., Ichang'i and Dindi E.W. (1994). The geology, structures and tectonics of the Mozambique belt in Kajiado district, S.W. Kenya. In: Muhongo, S. (Ed.) Proceedings of the International Geological Field Conference on the Mozambique belt in East Africa, IGCP 348 Field meeting in Arusha, Tanzania and Voi, Kenya, pp. 24-25.

Miyake, A. and Suwa, K. (1981). Geological structure of the Uvete dome, Kenya. 6th Prelim. Rept. Afr. Studies, Nagoya University, pp. 33-41, Japan.

Miyakawa, K. and Suwa, K. (1979). The Kalama psammitic gneisses from the Kalama Hill, Machakos area, Kenya. $4^{\text {th }}$ Prelim. Rept. Afr. Studies, Nagoya University, pp. 113-122, Japan.

Mosley, P.N. (1993). Geological Evolution of the Late Proterozoic "Mozambique Belt" of Kenya. Tectonophys., v. 221, pp. 223-250.

Muhongo, S. (1991). The Mozambique Belt: A Polyorogenic mobile belt. In: Muhongo, S. (ed.). Geology for Economic Development.UNESCO, Newslett., v. 8, pp. 5-14.

Muhongo, S. (1994). Neoproterozoic collision tectonics in the Mozambique belt of East Africa: evidence from the Ulunguru Mts., Tanzania. Journ. Afr. Earth Sci., v. 19, pp. 153-168. 
Muhongo, S. (1998). Anatomy of the Mozambique belt of eastern and southern Africa. Journ. Afr. Earth Sci., v. 27 , pp. 142.

Muhongo, S., Hauzenberger, C. and Sommer H. (2003), Vestiges of the Mesoproterozoic Events in the Neoproterozoic Mozambique belt: the Eastern African Perspective in the Rodinia puzzle. Gondwana Research

Nureki, T., Suwa, K., Biyajima, K., Saka, Y. and Yusa, Y. (1977). Tectonic evolution of the Mozambique belt in area south-east of Machakos, Kenya. 2nd Prelim. Rept. Afr. Studies, Nagoya University, pp. 33-41, Japan.

Nyamai, C.M., Mathu, E.M. and Ngecu, W.M. (1993). A review of the geology of the Mozambique belt in Kenya. In: Peters, J.W., Kesse, G.O. and Acquah, P.C. (Eds.). Proceedings of the $9^{\text {th }}$ International Geological conference of the Geological Society of Africa, Accra, Ghana, pp. 334-347.

Nyamai, C.M. (1995). Petrography and Geochemistry of the Mozambique belt of the Matuu area, central Kenya. In: Muhongo, S. (ed.) Geology for Sustainable Development, UNESCO, Geol. Econ. Devel. Newslett., v.10, pp. 154-155.

Nyamai, C.M., Opiyo-Akech, N., Gaciri, S.J. and Fujimaki, H. (1999). Geochemistry and Tectonomagmatic affinities of the Mozambique belt intrusive rocks in Matuu-Masinga area, central Kenya. Gondwana Res., v. 2(3), pp. 387-399.

Nyamai,C.M., Opiyo-Akech, N., Gaciri, S.J., and Fujimaki, H. (2000a). Structures, Metamorphism and Geochronology of the Mozambique belt metamorphic and intrusive rocks from MatuuMasinga area, central Kenya. Afr. Journ. Sci. Techn. (AJST), Science and Engineering Series, v. 1(1), pp. 47-55.

Nyamai, C.M., Opiyo-Akech, N., Gaciri, S.J., Johansson, B., and Sato,Y. (2000b). Petrography, mineral chemistry and thermobarometry of the Neoporoterozoic Mozambique belt rocks of MatuuMasinga area, central Kenya. In: Mukhopadhaya, D., Ghosh, S.S., Chakrabarti, B.K., Sanyai, S. and Gupta, S.D. (Eds.) Proceedings of the International seminar on Precambrian crust in Eastern and Central India, UNESCO-IUGS-IGCP-368, J. Geol. Surv. India Spl. Pub., No. 57, pp. 296-316.
Nyamai, C.M., Gaciri, S.J., Opiyo-Akech, N., Johansson, B., and Sato,Y. (2002). Conditions of Pyroxene Crystallization and Thermobarometry of the Neoproterozoic Mozambique belt intrusive rocks of Matuu-Masinga area, central Kenya. In: Nyamai, C.M. and Maimba, M. (Eds.) Proceedings of the $8^{\text {th }}$ and $9^{\text {th }}$ Regional Conference of the Geology of Kenya, Pub. Geol. Soc. Kenya, pp. 116-122.

Nyambok, I.O., Chorowicz, J. and Mathu, E.M. (1993). The Late Proterozoic Yatta Shear Zone: A possible lateral ramp across the Kenya Rift. In: Opiyo-Akech, N., (Ed.) Proceedings of the 5th Conference on the Geology of Kenya- Geology for sustainable Development, pp. 69-77. UNEP/ UNESCO, Nairobi.

Ochieng, J.O. (1993). Petrology of the gabbroic suite of rocks occurring south-east of Kenya. In: OpiyoAkech, N. (Ed.) Proceedings of the 5th Conference of the Geology of Kenya - Geology for sustainable Development, pp. 33-36. UNEP/ UNESCO, Nairobi.

Opiyo-Akech, N. and Nyamok, I.O. (1984). Precambrian geology of the Ishiara area, Kenya. Journ. Afr. Earth Sci., v. 2, No.1, pp. 61-65.

Pearce, J.A. and Cann, J.R. (1973). Tectonic setting of basic volcanic rocks determined using trace element analyses. Earth Planet. Sci. Lett., v. 19, pp. 290-300.

Pearce, J.A. and Norry, M.J. (1979). Petrogenetic implications of $\mathrm{Ti}, \mathrm{Zr}, \mathrm{Y}$ and $\mathrm{Nb}$ variations in volcanic rocks. Contrib. Mineral. Petrol., v. 69, pp. 33-47.

Pearce, J.A., Alabaster, T., Shelton, A.W. and Searle, M.P. (1981). The Oman ophiolite as a Cretaceous arcbasin complex: evidence and implications. Phil. Trans. Roy. Soc. London, v. 300A, pp. 299-317.

Pearce, J.A. (1982). Trace element characteristics of lavas from destructive plate boundaries. In: Thorpe, R.S (Ed.) Andesites, Orogenic Andesites and Related Rocks. Chichester: Wiley, pp. 525-548

Pearce, J.A., Harris, N.B.W. and Tindle, A.G. 1984. Trace element discrimination for the tectonic interpretation of granitic rocks. Journ. Petrol., v. 25, pp. 956-983.

Pohl, W. and Niedermayr, G. (1979). Geology of the Mwatate Quadrangle and the Vanadium Grossularite Deposits of the area. Rept. Geol. Surv. Kenya, No.101, 55p.

Pohl, W. and Horkel, A. (1980). Notes on the geology and mineral resources of the Mtito Andei - Taita area, southern Kenya. Mitt. österr. Geol. Ges., v. 73, pp. $135-152$. 
Prochaska, W. and Pohl, W. (1984). Petrochemistry of some mafic and ultramafic rocks from the Mozambique Belt, Northern Tanzania. Journ. Afr. Earth Sci., v.1, pp. 183 191.

Randel, R.P. (1970). Geology of the Laisamis area. Rept. Geol. Surv. Kenya, No.84, 24 pp.

Rix, P. (1967). Geology of the Kinna area. Rept. Geol. Surv. Kenya, No.8, 36 pp.

Saggerson, E.P. (1957). Geology of South Kitui area. Rept. Geol. Surv. Kenya, No.37.

Saggerson, E.P. (1962). Geology of the Kasigau-Kurase area. Rept. Geol. Surv. Kenya, No.51.

Saggerson, E.P. (1963). Geology of the Simba-Kibwezi area. Rept. Geol. Surv. Kenya, No.58.

Saltikoff, W., Githinji, J.K., Ombasa, L.K. and Rask, M. (1991). Assessment of Lolkidongai Wollastonite Deposit in Kajiado District, Kenya. Republic of Kenya, Ministry of Environment and Natural Resources, Mines and Geological Department, Geol. Mem., No.12, 21pp.

Sanders, L.D. (1954). Geology of the Kitui area. Rept. Geol. Surv. Kenya, No.30, 53p.

Sanders, L.D. (1965). Geology of the contact between the Nyanza Shield and the Mozambique belt in western Kenya. Rept. Geol. Surv. Kenya, No.7.

Shackleton, R.M. and Reiss, A.C. (1984). The relationship between regionally consistent streching lineations and plate motions. Journ. Struct. Geol., v. 6, pp. 111117.

Shackleton, R.M. (1986). Precambrian Collision Tectonics in Africa. In: Coward, M.P. and Ries, A.C. (Eds.) Collision Tectonics. Journ. Geol. Soc. London Spl. Publ., v.19, pp. 329-349.

Shibata, K. and Suwa, K. (1979). A geochronological study on granitoid gneiss from the Mbooni Hills, Machakos Area, Kenya. 4th Prelim. Rept. Afr. Studies, Nagoya University, pp. 163-167, Japan.
Shiozaki, H. (1983). Magnetic Susceptibility of the granitoid gneisses in the Mozambique belt of Kenya. $8^{\text {th }}$ Prelim. Rept. Afr. Studies, Nagoya University, pp. 121-134, Japan.

Simonet, C., Okundi, S. and Masai, P. (2002). General setting of coloured gemstone deposits in the Mozambique belt of Kenya - Preliminary considerations. In Nyamai, C.M. and Maimba, M. (eds.) Proceedings of the $8^{\text {th }}$ and $9^{\text {th }}$ Regional Conference of the Geology of Kenya, Pub. Geol. Soc. Kenya, pp. 123-138.

Stern, J.R. (1994). Arc assembly and continental collision in the Neoproterozoic East African Orogeny: Implications for the Consolidation of Gondwanaland. Annual Rev. Earth Planet. Sci. Lett., v. 22, pp. 319-351.

Stern, J.R. 2000. The East African Orogen (2000). Journ. Afr. Earth Sci., v. 30(4A), p.82.

Suwa, K., Nureki, H., Inoue, K., Biyajima, K. and Miyakawa, K. (1979). Geology and Petrology of the Machakos area, Kenya. 4th Prelim. Rept. Afr. Studies, Nagoya University, pp. 3-20, Japan.

Vearncombe, J.R. (1983). A dismembered ophiolite from the Mozambique belt, west Pokot, Kenya. Journ. Afr. Earth Sci., v.1, pp. 133-143.

Walsh, J. (1960). Geology of the area south of Taita Hills. Rept. Geol. Surv. Kenya, No.49.

Walsh, J. and Pulfrey, W. (1969). Geology and mineral resources of Kenya. $2^{\text {nd }}$ revision. Bull. Geol. Surv. Kenya, No.9.

Weiss, L.E. (1959). Structural analysis of the Basement System at Turoka, Kenya. Overseas Geol. Miner. Resour., v.7, pp. 123-153.

Williams, L.A.J. (1966). Geology off the Chanler's Falls area, Kenya. Rept. Geol. Surv. Kenya, No.75.

Williams, L.A.J. (1967). The Kilimanjaro Volcanic rocks of the Amboseli area, Kenya. PhD dissertation, Univ. of East Africa. 